\title{
EFFECTS OF METYRAPONE ON REPRODUCTIVE ORGANS OF THE MEADOW VOLE, MICROTUS PENNSYLVANICUS
}

\author{
J. N. PASLEY \\ Department of Physiology and Biophysics, University of Arkansas Medical Center, \\ Little Rock, Arkansas 72201, U.S.A.
}

(Received 5th March 1974)

\begin{abstract}
Summary. Reproductive organ weights and histology were examined in male and female voles, Microtus pennsylvanicus, which had received daily injections of metyrapone $(100 \mathrm{mg} / \mathrm{kg}$ ) or saline for 21 days from 30 days of age. In females receiving metyrapone, body weight and weights of ovaries and uteri were significantly decreased. In metyrapone-treated males, seminal vesicles were $70 \%$ lighter than in saline-injected controls. Histological examination of the reproductive organs confirmed inhibition of reproductive development and maturation in metyrapone-treated voles. The results with metyrapone lend further support to the hypothesis that increased pituitary-adrenal activity may impair reproductive function in rodents.
\end{abstract}

In the meadow vole, Microtus pennsylvanicus, the development and function of the reproductive organs may be inhibited at high levels of population density (Christian, Lloyd \& Davis, 1965; Pasley \& McKinney, 1973). Increased pituitary-adrenocortical secretory activity may provide a density-dependent negative feedback system that inhibits reproduction (Christian et al., 1965). Moreover, the administration of exogenous adrenocorticotrophin (ACTH) has been found to inhibit reproductive maturation in meadow voles of both sexes (Pasley \& Christian, 1971).

The present study was undertaken to test whether the inhibitory effects of exogenous ACTH on the vole reproductive tract would also occur with increased endogenous ACTH secretion. Endogenous ACTH secretion was stimulated, therefore, by daily injections of metyrapone, a specific $11 \beta$-hydroxylase inhibitor, which induces a compensatory increase in ACTH production (Liddle, Island \& Meador, 1962).

A colony of meadow voles derived from voles trapped in the wild, was maintained in our laboratory and used in this study. Voles of both sexes were housed at $24^{\circ} \mathrm{C}$ with $14 \mathrm{hr}$ light $/ 24 \mathrm{hr}$. They were caged in sexually separate groups of three to four per cage, and were provided with water, sunflower seeds and Rockland mouse pellets in excess of consumption. All voles were weaned at 21 days of age and assigned to experimental groups as indicated in Table 1. At 30 days of age, male and female voles received either $100 \mathrm{mg}$ metyrapone 
(metopirone ditartrate, CIBA) $/ \mathrm{kg}$ or $0.9 \%$ saline for 21 days. All injections were administered intraperitoneally once daily between 08.00 and 10.00 hours in a volume of $0.1 \mathrm{ml}$. Voles were killed $24 \mathrm{hr}$ after the last injection and weighed. They were then disembowelled and the remainder of each animal was placed in $10 \%$ neutral buffered formalin. All organs were weighed wet after fixation. Tissues were embedded in paraffin wax, sectioned at $6 \mu \mathrm{m}$, stained with haematoxylin and eosin, and examined by light microscopy. Treatment means were compared using Student's $t$ test and probability levels of 0.05 or less were considered statistically significant.

Daily injections of metyrapone in immature female voles resulted in statistically significant changes in body weight and in weights of ovaries and uteri (Table 1). After metyrapone treatment, final body weight in female voles

Table 1. Body and organ weights of voles receiving saline or metyrapone

\begin{tabular}{|c|c|c|c|c|c|c|c|}
\hline & $\begin{array}{l}\text { No. of } \\
\text { voles }\end{array}$ & $\begin{array}{l}\text { Initial } \\
\text { body wt } \\
(\mathrm{g})\end{array}$ & $\begin{array}{l}\text { Final body } \\
\text { wt }(g)\end{array}$ & $\begin{array}{l}\text { Adrenal } \\
w t(m g)\end{array}$ & $\begin{array}{c}\text { Kidney } \\
w t(m g)\end{array}$ & $\begin{array}{c}\text { Gonad } \\
\text { wt }(m g)\end{array}$ & $\begin{array}{l}\text { Seminal } \\
\text { vesicle or } \\
\text { uterus wt } \\
\quad(m g)\end{array}$ \\
\hline $\begin{array}{l}\text { Males } \\
\text { Saline } \\
\text { Metyrapone }\end{array}$ & $\begin{array}{l}9 \\
8\end{array}$ & $\begin{array}{l}20 \cdot 8 \pm 0 \cdot 8 \\
20 \cdot 1 \pm 1 \cdot 4\end{array}$ & $\begin{array}{l}22 \cdot 9 \pm 1 \cdot 4 \\
23 \cdot 6 \pm 0 \cdot 9\end{array}$ & $\begin{array}{r}7.1 \pm 0.6 \\
10.2 \pm 0.8\end{array}$ & $\begin{array}{l}305 \cdot 5 \pm 20 \cdot 8 \\
299 \cdot 6 \pm 8 \cdot 6\end{array}$ & $\begin{array}{l}797 \pm 64 \cdot 6 \\
645 \pm 61 \cdot 5\end{array}$ & $\begin{array}{l}62 \cdot 9 \pm 15 \cdot 1 \\
18 \cdot 8 \pm 5 \cdot 5\end{array}$ \\
\hline $\begin{array}{l}\text { Females } \\
\text { Saline } \\
\text { Metyrapone }\end{array}$ & $\begin{array}{l}10 \\
10\end{array}$ & $\begin{array}{l}20 \cdot 4 \pm 1 \cdot 1 \\
21 \cdot 6 \pm 1 \cdot 2\end{array}$ & $\begin{array}{l}25 \cdot 6 \pm 0.9 \\
22.5 \pm 0.7\end{array}$ & $\begin{array}{l}22 \cdot 3 \pm 1 \cdot 4 \\
19 \cdot 4 \pm 6 \cdot 3\end{array}$ & $\begin{array}{l}302 \cdot 5 \pm 13 \cdot 4 \\
272 \cdot 3 \pm 9 \cdot 5\end{array}$ & $\begin{array}{r}16.7 \pm 3.6 \\
5.9 \pm 0.8\end{array}$ & $\begin{array}{l}77 \cdot 6 \pm 1 \cdot 7 \\
40 \cdot 7 \pm 7 \cdot 8\end{array}$ \\
\hline
\end{tabular}

Metyrapone $(100 \mathrm{mg} / \mathrm{kg})$ or saline $0.9 \%$ was injected intraperitoneally once daily for 21 days. The results are expressed in terms of Means \pm S.E.

was $12 \%$ less $(P<0.05)$, the ovaries were $65 \%$ lighter and the uteri weighed $48 \%$ less than in the controls. Although the numbers of primary and developing follicles, and tertiary follicles, were not significantly different in the two groups, most tertiary follicles were small and atretic in voles treated with metyrapone. The uteri in metyrapone-treated females were infantile with dense endometria and no glandular development. The weights of the adrenals and kidneys of female voles were not different between groups (Table 1).

Seminal vesicle weights of young male voles treated with metyrapone were less than those from controls while adrenal weights were significantly greater (Table 1). Seminal vesicle weights were $70 \%$ lighter $(P<0.05)$ while adrenal weights were $30 \%(P<0.01)$ heavier. Testicular and kidney weights and histology of metyrapone-treated voles did not differ from those of voles treated with saline.

The data indicate that chronic treatment with metyrapone interferes with reproductive maturation in meadow voles of both sexes. Inhibition of reproductive development among voles treated with metyrapone was indicated by lighter ovaries and uteri among females and by lighter seminal vesicles among males.

Metyrapone inhibits major corticosteroid formation by blocking $11 \beta$ hydroxylation and inducing a compensatory increase in ACTH production 
(Liddle et al., 1962). Moreover, ACTH stimulation in the absence of $11 \beta$ hydroxylation apparently enhances adrenal androgen secretion (Bongiovanni \& Eberlein, 1961; Reynolds \& Ulstrom, 1963).

The reason for the absence of adrenal enlargement in females treated with metyrapone is not known but may be related to the involution of the adrenal cortex or to quantitative changes in the corticosteroids secreted. As already noted, metyrapone induces increased androgen production and androgen treatment has been shown to decrease the size of the adrenal cortex (Kitay, 1962; Callard \& Leathem, 1963). One explanation, therefore, may be that metyrapone induced an involution of the inner adrenal cortical areas which offset the ACTH-induced increase in the fasciculata-reticularis zones in females. Another explanation may be that the absence of adrenal enlargement in female Microtus reflects the blockade of corticosterone production by metyrapone since heavier adrenals in females have been correlated with greater corticosterone secretion in females than in males (Seabloom, 1965).

Our results with metyrapone on body weight and the weights and morphology of reproductive organs of meadow voles are consistent with earlier findings following exogenous ACTH treatment in voles (Pasley \& Christian, 1971) with the exception that metyrapone had no effect on spermatogenesis.

It has been shown that gonadotrophin secretion and reproductive maturation can be inhibited by low doses of weak androgens (Varon \& Christian, 1963). Thus, suppression of gonadotrophin secretion by enhanced levels of adrenal androgens stimulated by metyrapone seems a likely possibility in this experiment.

The results of the present study with metyrapone lend further support to the hypothesis that increased pituitary-adrenocortical activity may impair reproductive function in voles. The hypothesis stated above provides a densitydependent negative feedback mechanism that is significant in the regulation of growth of natural and freely growing populations of small rodents.

This work was supported in part by USPHS grant GRS 5 SO1-RR-05350.

\section{REFERENCES}

Bongiovanni, A. M. \& Eberlein, W. R. (1961) Defects in steroidal metabolism of subjects with adrenogenital syndrome. Metabolism, 10,917.

Callard, G. V. \& Leathem, J. H. (1963) Gonadal influences on adrenal function. Am. Zoologist, 3, 401.

Ghristian, J. J., Lloyd, J. A. \& Davis, D. E. (1965) The rôle of endocrines in the self-regulation of mammalian populations. Recent Progr. Horm. Res. 21, 501.

KITAy, J. I. (1962) The effects of gonadal hormones on AGTH secretion. In Int. Congr. Hormonal Steroids, Milan, 1960. Excerpta Med. Int. Congr. Ser. 51, 88.

Liddle, G. W., Island, D. \& Meador, G. K. (1962) Regulation of corticotrophin secretion in man. Recent Progr. Horm. Res. 18, 125.

Pasley, J. N. \& Christian, J. J. (1971) Effects of AGTH on voles (Microtus pennsylvanicus) related to reproductive function and renal disease. Proc. Soc. exp. Biol. Med. 137, 268.

Pasley, J. N. \& McKinney, T. D. (1973) Grouping and ovulation in voles. F. Reprod. Fert. 34, 527.

Reynolds, J. W. \& Ulstrom, R. A. (1963) Studies of cortisol metabolism in a case of the hypertensive form of congenital adrenal hyperplasia: demonstration of the absence of $11 \beta$-hydroxylation. F. clin. Endocr. Metab. 23, 191.

Seabloom, R. W. (1965) Daily motor activity and corticosterone secretion in the meadow vole. $\mathcal{F}$. Mammal. 46, 286.

Varon, H. H. \& Ghristian, J. J. (1963) Effects of adrenal androgens on immature female mice. Endocrinology, 72, 210. 